\title{
DETERMINANTY ZARZĄDZANIA JAKOŚCIĄ CYFROWEJ USLUGI POCZTOWEJ- WYBRANE PROBLEMY
}

\begin{abstract}
Streszczenie: Celem artykułu jest przedstawienie znaczenia wybranych determinantów w kształtowaniu jakości cyfrowej usługi pocztowej. Pierwsza część opracowania zawiera teoretyczne ramy zarządzania jakością usług, charakterystykę rynku pocztowego oraz przybliżenie cyfrowych usług pocztowych. Następnie, przedstawione zostały wyniki anonimowej ankiety konsumenckiej, przeprowadzonej na grupie pięćdziesięciu klientów korzystających z cyfrowych usług pocztowych, które przyczyniły się do sformułowania wniosków z zakresu znaczenia poszczególnych determinantów jakości cyfrowej usługi pocztowej.
\end{abstract}

Słowa kluczowe: cyfryzacja, determinanty jakości, jakość, zarządzanie jakością.

\section{Wstęp}

Na rynku usług pocztowych w ostatnich latach zachodzi szereg zmian. Zmiany te dotyczą zarówno popularności poszczególnych usług, jak i funkcjonowania. W Polsce i na świecie notowany jest regularny spadek liczby nadawanych w sposób tradycyjny przesyłek listowych, rośnie za to popularność przesyłek kurierskich. Po okresie stagnacji, od 2017 roku rośnie wartość polskiego rynku pocztowego. Pojawiają się nowe przedsiębiorstwa świadczące usługi kurierskie, a te już działające prowadzą działania rozwojowe, co wymusza wykorzystywanie narzędzi walki konkurencyjnej [1, 2].

Potrzeby i oczekiwania klientów korzystających z usług pocztowych, zgodnie z wynikami badań, zmieniają się [3]. Preferowanie przesyłek kurierskich oznacza, iż determinanty usługi pocztowej decydujące o poziomie jej jakości dla klienta, są inne niż jakiś czas temu. Przesyłkę kurierską od tradycyjnej paczki lub listu wyróżnia wprawdzie wyższa cena, ale także większa wygoda nadania i odbioru, szybszy czas realizacji oraz duży zakres usług dodatkowych (np. śledzenie, dostawa na godziny itp.).

${ }^{1}$ Mgr inż., Wydział Zarządzania, Politechnika Częstochowska, Al. Armii Krajowej 19B, 42-200 Częstochowa, Polska, e-mail: kamilakowalik93@gmail.com, ORCID ID: 0000-0002-2808-0191

2 Dr inż., Katedra Inżynierii Produkcji i Bezpieczeństwa, Wydział Zarządzania, Politechnika Częstochowa, Al. Armii Krajowej 19B, 42-200 Częstochowa, Polska, e-mail: dorota.klimeckatatar@wz.pcz.pl, ORCID ID: 0000-0001-6212-6061 
Wzrasta także obszar oferty przedsiębiorstw świadczących usługi pocztowe, z której można korzystać elektronicznie. Jest to spowodowane przez postępującą cyfryzację, która od kilku lat uwidacznia się także na rynku usług pocztowych. Cyfryzacja, czyli wzrost wykorzystania technologii cyfrowych, wynika z ich stopniowego i nieustannego rozwoju, co przekłada się na podejście, iż Internet nie jest rewolucją w usługach, ale efektem ich ewolucji [4,5].

Cyfrowe usługi pocztowe są dostępne w Polsce od roku 2010, jednak dopiero ostatnie kilka lat, w trakcie których opracowano cyfrowe platformy usług pocztowych, przyczyniły się do wzrostu ich popularności. Obecnie, w ramach powszechnych cyfrowych usług pocztowych możliwe jest: nadanie i opłacenie kartki lub listu zwykłego i poleconego dostarczonego elektronicznie lub tradycyjnie; nadanie i opłacenie paczki lub przesyłki kurierskiej (którą należy dostarczyć do punktu pocztowego bez konieczności oczekiwania w kolejce). Ponadto, skorzystać można także z szeregu usług dodatkowych: znaczek z własną grafiką, kartka z własną grafiką, monitorowanie korespondencji własnej oraz firmowej, śledzenie przesyłek, elektroniczne potwierdzenie odbioru, zakupów artykułów niezbędnych do realizacji przesyłek. Dla przedsiębiorstw oferuje się także usługi marketingowe i contact center [6].

Usługi elektroniczne cechują się szeregiem korzyści zarówno dla klientów, jak i dla przedsiębiorstw. Wśród zalet korzystania z dokonywania zakupów w sposób elektroniczny zalicza się głównie [7]: wygodę (dokonywanie transakcji bez wychodzenia z domu), dostępność czasową (możliwość korzystania z usług i dokonywania zakupów o każdej porze w każdy dzień tygodnia), dostępność produktów/usług (często szerszy asortyment/ zakres usług lub inny asortyment/ zakres usług niż w punkcie stacjonarnym), niższą cenę, możliwość poznania opinii innych użytkowników, możliwość porównania ofert przedsiębiorstw.

Korzyści dla przedsiębiorstw obejmują między innymi: redukcję kosztów zatrudnienia, redukcję kosztów obsługi klienta, wzrost szybkości obsługi klientów, wzrost satysfakcji klientów, polepszenie pozycji konkurencyjnej przedsiębiorstw.

Od kilku lat regularnie prowadzone są badania, których celem jest wskazanie determinantów wpływających na korzystanie z handlu elektronicznego. Dotyczą one demografii, typologii klientów, ale także poszczególnych sektorów, branż, pojedynczych przedsiębiorstw, produktów lub usług. Najczęściej wskazuje się, iż decyzja klienta odnośnie skorzystania z zakupów w sieci uwarunkowana jest wieloma czynnikami. Za podstawowe uważane są: cena, jakość, marka, reklama, opakowanie, przyzwyczajenie, kraj pochodzenia produktu. Cechy dodatkowe to potrzeba, opinia, obsługa klienta, warunki i gust [8]. 
Zgodnie z badaniami Infas klienci decydują się na dokonywanie transakcji elektronicznie oceniając następujące kryteria (przedstawione według istotności) [9]: cena, bezpieczeństwo, gwarancja zwrotu pieniędzy, wiarygodność, ochrona danych osobowych, opinie klientów, łatwość obsługi, rekomendacje znajomych, popularność przedsiębiorstwa, oferta.

Wobec przedstawionych informacji można dostrzec problematykę zarządzania jakością cyfrowych usług pocztowych spowodowaną szerokim zakresem zmieniających się determinantów tego rodzaju usług. Zarządzanie jakością również ewoluowało w miarę upływu czasu. Na początku XX wieku identyfikowało się tzw. „,inspekcję jakości”, w połowie stulecia było to „zapewnienie” jakości, które przekształciło się w „sterowanie" jakością, a obecnie znane jako „zarządzanie jakością" obejmuje zagadnienia planowania, zapewnienia, sterowania i doskonalenia jakości będąc postrzegane jako filozofia funkcjonowania przedsiębiorstwa [10].

\section{METODOLOGIA BADAŃ}

Dla potrzeb badań wśród klientów korzystających z cyfrowych usług pocztowych drogą elektroniczną przeprowadzona została anonimowa ankieta, której celem było dokonanie oceny istotności poszczególnych wybranych determinantów w kształtowaniu jakości cyfrowej usługi pocztowej. W sondażu diagnostycznym wzięło udział 30 respondentów. Struktura grupy badanej przedstawiona jest w tabeli 1 .

Tabela 1. Struktura respondentów

\begin{tabular}{|c|c|c|c|}
\hline Wiek & Mężczyźni, \% & Kobiety, \% & Razem, \% \\
\hline $18-24$ & 13,33 & 13,33 & 26,67 \\
\hline $25-39$ & 16,67 & 26,67 & 43,33 \\
\hline $40-59$ & 20 & 10 & 30 \\
\hline $60<$ & 0 & 0 & 0 \\
\hline \multicolumn{3}{|r}{} & $\mathbf{1 0 0}$ \\
\cline { 3 - 4 }
\end{tabular}

Źródto: opracowanie własne

Grupą dominującą wśród respondentów są kobiety w wieku 25-39 lat, stanowiące $26,67 \%$ ankietowanych. Warto zauważyć, iż żaden uczestnik badania nie należał do grupy osób starszych (60 i więcej lat), co może być spowodowane elektronicznym kanałem przeprowadzenia badania oraz niższą popularnością usług cyfrowych wśród osób należącej do danej grupy wiekowej, co uwarunkowane jest wieloma złożonymi czynnikami. 
Arkusz anonimowej ankiety składał się z metryczki oraz ośmiu stwierdzeń, ocenianych przez respondentów za pomocą skali ważności w oparciu o założenia:

\section{5- bardzo wysoki wptyw}

1- bardzo niski wplyw.

Determinanty pocztowej usługi cyfrowej wybrane do badania to:

- cena (koszt usługi cyfrowej oraz inne niezbędne koszty, jakie trzeba ponieść, aby z niej skorzystać),

- dostępność i kompletność informacji (łatwość wyszukiwania informacji, zawarcie na stronie internetowej/w aplikacji wszystkich informacji ważnych dla klienta, aby podjął decyzję o skorzystaniu z usługi),

- zakres usług (oferta usług cyfrowych, możliwość skorzystania z całkowitej pocztowej usługi cyfrowej- np. list polecony online lub usługi częściowo cyfrowej, np. nadanie i opłacenie paczki, którą należy dostarczyć do punktu),

- kontakt (z biurem obsługi klienta, w celu uzyskania informacji, pomocy, złożenia reklamacji; czas nawiązania kontaktu, kompetencje personelu, empatia);

- szybkość realizacji usługi (czas upływający od zawarcia transakcji online do momentu realizacji usługi),

- bezbłędność realizacji usługi (brak pomyłek w trakcie realizacji usługi),

- zakres metod płatności (ocena satysfakcji z dostępności metod płatności),

- łatwość obsługi strony internetowej/aplikacji.

Przeprowadzone badania składały się z następujących etapów: opracowanie ankiety, przeprowadzenie ankiety wśród klientów, opracowanie wyników (w postaci wykresów słupkowych dla każdej determinanty), wyliczenie średniej arytmetycznej w celu porównania istotności determinantów oraz interpretacja wyników.

\section{Wyniki przeprowadzonych badań - znaczenie determinantów jakości cyfrowych usług pocztowych}

Opinia respondentów w zakresie istotności pierwszej determinanty jakości cyfrowej usługi pocztowej poddanej badaniu (ceny) przedstawiona jest na rysunku 1.

Opracowanie statystyczne wskazują cenę jako jeden z głównych czynników dokonywania przez Polaków zakupów online. Respondenci poddani badaniu również doceniają bardzo wysoki wpływ (53,33\%) oraz wysoki wpływ $(46,67 \%)$ ceny na jakość cyfrowej usługi pocztowej. Warto zauważyć, iż żaden respondent nie wskazał średniego ani niskiego wpływu. 


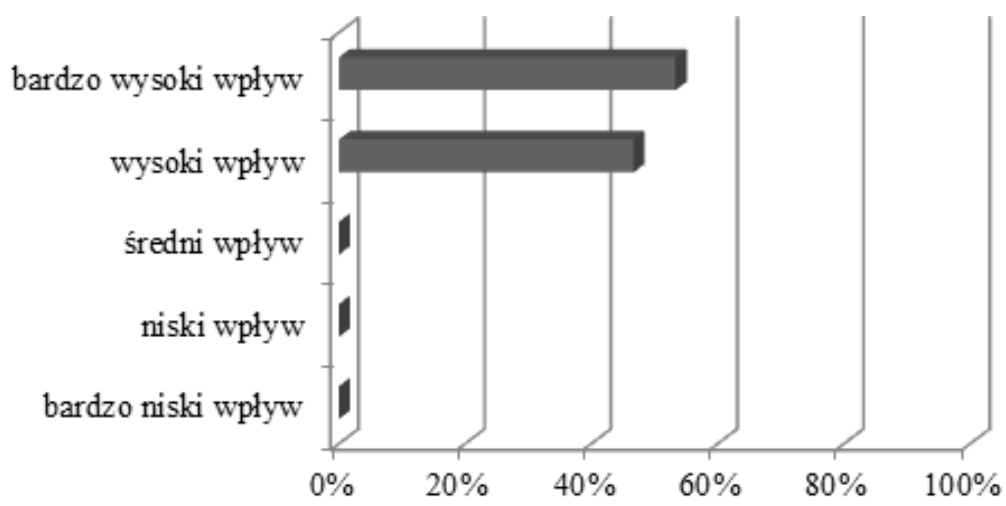

Rys. 1. Wpływ ceny na jakość cyfrowej usługi pocztowej-opinia respondentów Źródto: opracowanie wtasne

Kolejna determinanta poddana badaniu to dostępność i kompletność informacji. Odpowiedzi respondentów zostały zawarte na rysunku 2.

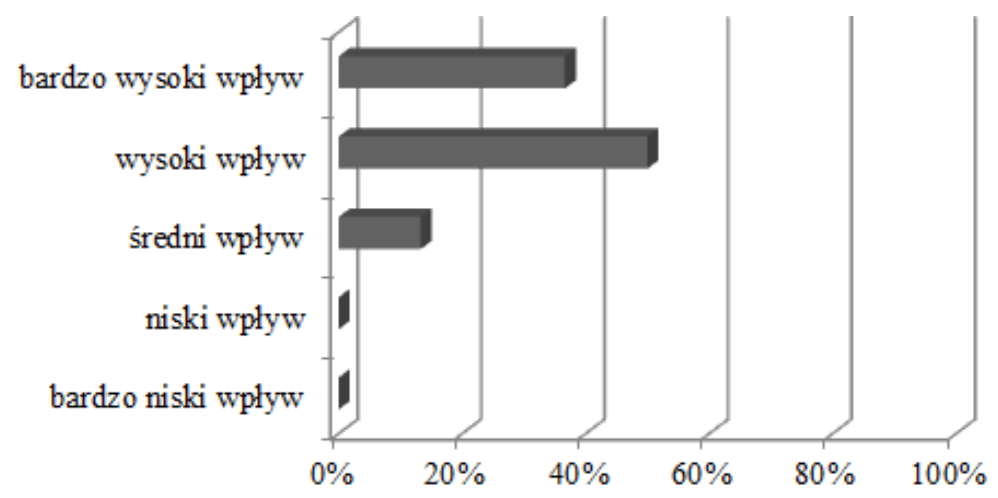

Rys. 2. Wplyw dostępności i kompletności informacji na jakość cyfrowej ustugi pocztowejopinia respondentów

Źródło: opracowanie własne

Dane przedstawione na rysunku 2 wskazują, iż dostępność i kompletność informacji to również bardzo ważna determinanta jakości cyfrowej usługi pocztowej. Połowa grupy badanej wpływ ten uważa za silny a $36,67 \%$ za bardzo silny. Po raz pierwszy pojawiły się niższe oceny- nieco ponad co dziesiąty respondent $(13,33 \%)$ wskazuje, iż wpływ dostępności/kompletności informacji na jakość cyfrowej usługi pocztowej jest średni.

Następnie ocena istotności została dokonana przez respondentów dla czynnika jakim jest zakres usług (oferta) (rysunek 3). 


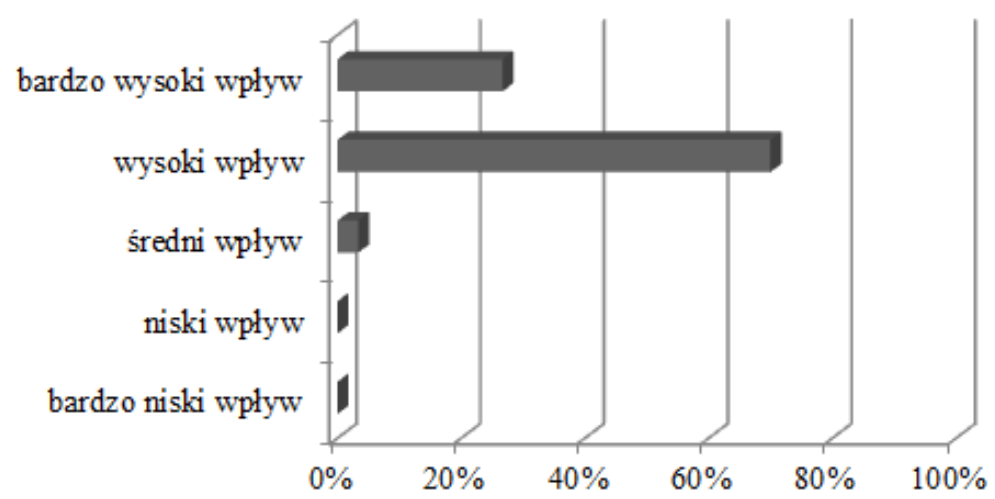

Rys. 3. Wplyw zakresu usług na jakość cyfrowej ustugi pocztowej-opinia respondentów Źródto: opracowanie własne

Najczęściej wybieraną przez respondentów oceną znaczenia zakresu usług w kształtowaniu jakości cyfrowych usług pocztowych była 4 . Aż 70\% respondentów wskazało, iż wpływ tego czynnika jest wysoki, a ponad co czwarty z nich $(26,67 \%)$ uznaje wpływ ten za bardzo wysoki. Należy wskazać, iż pojawiła się także ocena mówiąca o średnim wpływie (3,33\%), ale żaden respondent nie ocenił go jako niski.

$\mathrm{W}$ procesie usługowym nieprzeprowadzanym cyfrowo identyfikowana jest znaczna interakcja pomiędzy personelem a klientem i atrybuty tej interakcji stanowią podstawę badań jakości tego rodzaju usług. Kontakt innego rodzaju jest także obecny w cyfrowych usługach pocztowych. Opinię respondentów na temat tej determinanty zawiera rysunek 4.

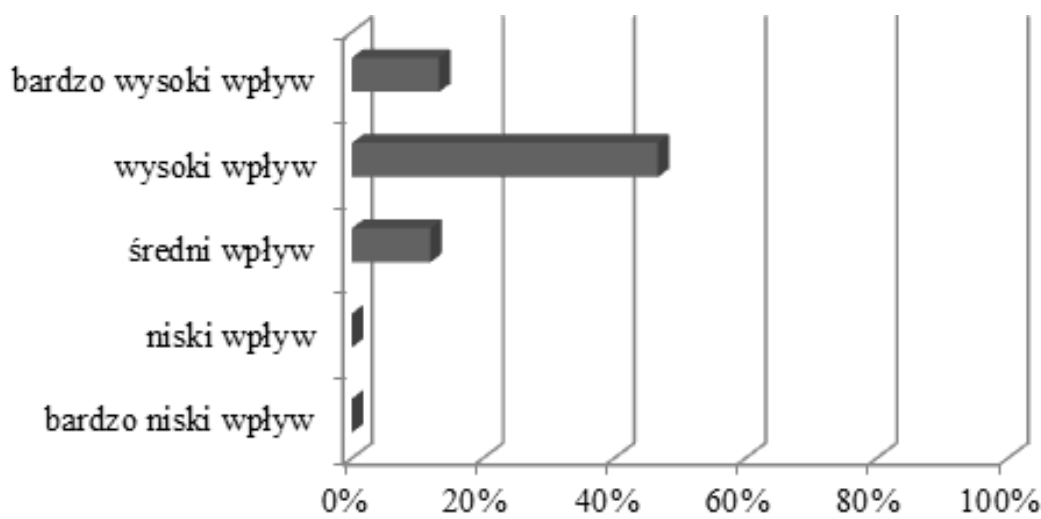

Rys. 4. Wplyw kontaktu na jakość cyfrowej ustugi pocztowej-opinia respondentów Źródto: opracowanie własne 
Dane przedstawione na rysunku 4 znacznie różnią się od ocen przypisanych trzem omówionym już czynnikom. Największy odsetek respondentów $(46,67 \%)$ wskazuje na wysoki wpływ tej determinanty na jakość cyfrowej usługi pocztowej. Jedynie $13,33 \%$ respondentów wpływ ten uważa za bardzo silny. Należy podkreślić znaczną grupę respondentów (40\%), według której oddziaływanie tego czynnika jest średnie.

Kolejne dwie determinanty poddane ocenie respondentów zostały zaczerpnięte ze standardowego arkusza metody Servqual. Pierwszym z nich jest szybkość realizacji usługi, która niezależnie od sposobu jej zawarcia, kształtuje jakość usług (rysunek 5).

Respondenci spośród pięciu możliwych w tym przypadku wskazali jedynie dwie oceny. Znacząca większość z nich $(76,67 \%)$ wpływ szybkości realizacji na jakość cyfrowej usługi pocztowej uważa za wysoki, a 23,33\% respondentów za bardzo wysoki.

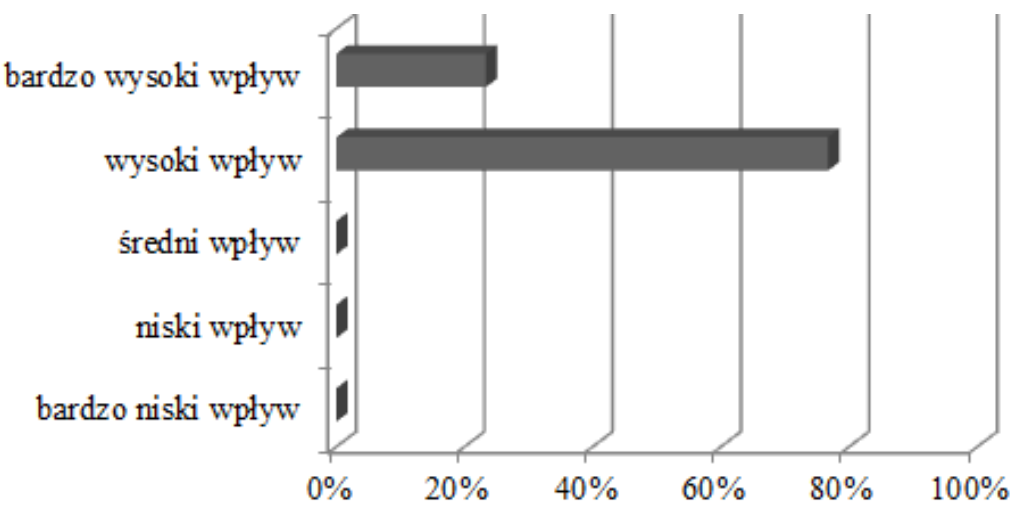

Rys. 5. Wplyw szybkości realizacji na jakość cyfrowej usługi pocztowej-opinia respondentów

Źródto: opracowanie własne

Ze wskazanej metody badania jakości usług dla potrzeb opracowania wybrano również bezbłędność realizacji, która w odniesieniu do cyfrowej usługi pocztowej może dotyczyć zarówno obszaru zawierania jak i świadczenia usługi. Opinię respondentów przedstawia rysunek 6 .

Dane zawarte na rysunku 6 świadczą o tym, iż respondenci inaczej postrzegają znaczenie szybkości i bezbłędności realizacji w jakości cyfrowej usługi pocztowej. $40 \%$ respondentów poddanych badaniu wpływ tej determinanty ocenia jako bardzo silny, a $36,67 \%$ z nich jako silny. Należy jednak zauważyć, iż prawie co czwarty ankietowany $(23,33 \%)$ przyznało ocenę świadczącą o średnim oddziaływaniu tego czynnika na jakość. 


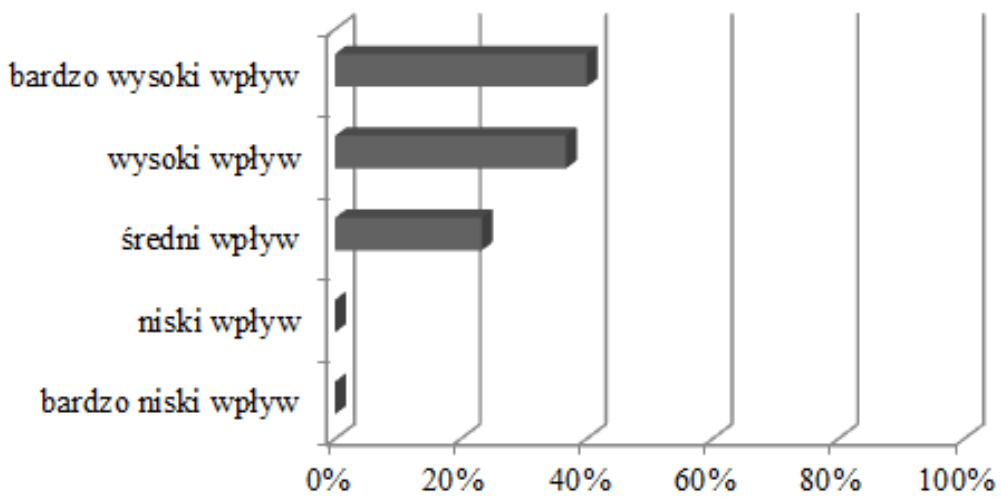

Rys. 6. Wpływ bezblędności realizacji na jakość cyfrowej usługi pocztowej-opinia respondentów

Źródto: opracowanie własne

Kolejna determinanta wybrana dla potrzeb badania to czynnik przypisany korzystaniu z usług cyfrowych- łatwość obsługi strony internetowej lub aplikacji (rysunek 7).

Tak jak w przypadku ceny oraz szybkości realizacji, respondenci zdecydowali się wybrać jedynie dwa warianty ocen. Aż $70 \%$ z nich uważa, iż wpływ łatwości obsługi strony internetowej lub aplikacji na jakość cyfrowej usługi pocztowej jest bardzo silny. Pozostały odsetek ankietowanych (30\%) wpływ ten postrzega jako silny.

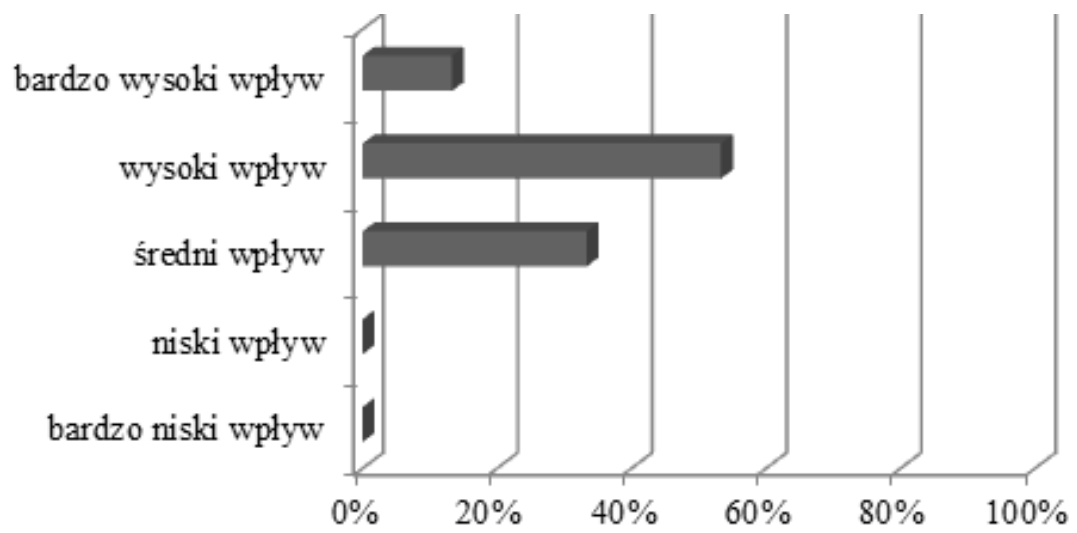

Rys. 7. Wpływ tatwości obstugi strony internetowej/aplikacji na jakość cyfrowej uslugi

$$
\text { pocztowej-opinia respondentów }
$$

Źródto: opracowanie własne

Ostatnim kryterium poddanym ocenie respondentów w niniejszym badaniu jest dostępność metod płatności (rysunek 8). 


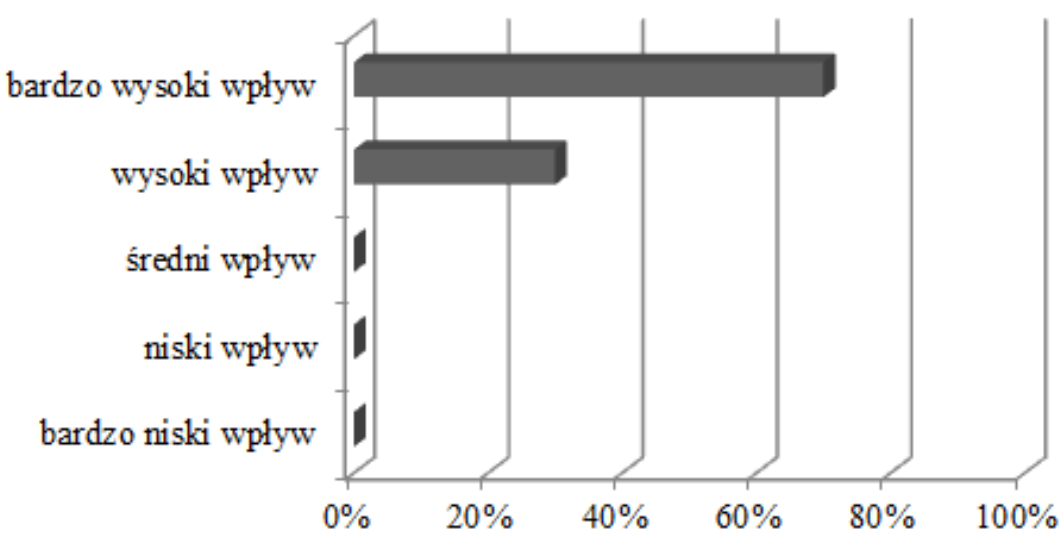

Rys. 8. Wplyw dostęności metod platności na jakość cyfrowej ustugi pocztowej-opinia respondentów

Źródło: opracowanie własne

Ponad połowa ankietowanych $(53,33 \%)$ wskazuje na silny wpływ dostępności metod płatności na jakość cyfrowej usługi pocztowej. Jedynie nieco ponad co dziesiąty z nich (13,33\%) wpływ ten postrzega jako bardzo silny. Aż 33,33\% respondentów jest zdania, iż oddziaływania tej determinanty na jakość jest średnie.

Aby dokonać porównania obliczona została średnia wpływu dla każdej determinanty poddanej badaniu przez respondentów (tabela 2).

Tabela 2. Średnia wplywu determinantów na jakość cyfrowych ustug pocztowych

\begin{tabular}{|c|c|}
\hline Determinanta & Średnia wplywu [\%] \\
\hline cena & 4,53 \\
\hline dostępność/kompletność informacji & 4,23 \\
\hline zakres usług & 4,23 \\
\hline kontakt & 3,73 \\
\hline szybkość realizacji & 4,23 \\
\hline bezbłędność realizacji & 4,17 \\
\hline dostępność metod płatności & 3,8 \\
\hline łatwość obsługi strony internetowej/ aplikacji & 4,7 \\
\hline
\end{tabular}

Źródto: opracowanie własne

Dane zawarte w tabeli 2 wskazują, iż w przeprowadzonym badaniu według respondentów najważniejszą determinantą jakości cyfrowych usług pocztowych jest łatwość obsługi strony internetowej lub aplikacji. Druga średnia wartość przypisana jest cenie. Respondenci $\mathrm{z}$ równą, wysoką istotnością ocenili także 
dostępność/kompletność informacji, zakres usług oraz szybkość realizacji. Na przedostatnim miejscu według średniej arytmetycznej znalazł się kontakt, a wśród wybranych, poddanych badaniu determinantów najmniejszy wpływ na jakość cyfrowej usługi pocztowej został przypisany dostępności metod płatności.

\section{Podsumowanie}

Zarządzanie jakością cyfrowych usług pocztowych to złożone zagadnienie. Przede wszystkim, na podstawie przeprowadzonych badań należy przyjąć, iż ilość istotnych determinantów kształtujących jakość tego rodzaju usług jest spora. W związku z cyfryzacją oraz prognozowanym dalszym rozwojem usług pocztowych należy również brać pod uwagę zmieniające się warunki zarządzania.

Przeprowadzone badanie w obszarze ośmiu wybranych determinantów zarządzania jakością cyfrowych usług pocztowych wskazało, iż wśród nich największe znaczenie ma poziom łatwości obsługi strony internetowej lub aplikacji. Może to wynikać $\mathrm{z}$ faktu, iż z usług pocztowych korzystają klienci w różnym wieku, a wiek stanowi jeden $\mathrm{z}$ czynników poziomu kompetencji cyfrowych. Wśród najważniejszych determinantów znajduje się także cena, co stanowi potwierdzenie dotychczasowych badań w zakresie handlu elektronicznego, gdzie cena wymieniana jest jako jeden z pierwszych czynników branych pod uwagę przez klienta. Za najmniej ważne klienci w przeprowadzonym badaniu postrzegają wybór metod płatności oraz kontakt z obsługą klienta.

Przeprowadzone badania mogą stanowić podstawę do dalszych rozważań w zakresie zarządzania jakością cyfrowych usług pocztowych.

\section{Bibliografia}

[1.] Tochkov, K. (2015). The efficiency of postal services in the age of market liberalization and the Internet: evidence from Central and Eastern Europe, Utilities Policy, 36, 35-42.

[2.] Raport o stanie rynku pocztowego w 2017 roku, Urząd Komunikacji Elektronicznej, Warszawa 2018.

[3.] Szopiński, T. (2013). Czynniki determinujace korzystanie z handlu elektronicznego przez konsumentów, Handel Wewnętrzny, 6(347), 32-42.

[4.] Grzybowska-Brzezińska, M. \& Grzywińska-Rąpca, M. (2016). Determinanty e-zakupów na rynku żywności, Roczniki Kolegium Analiz Ekonomicznych, 40, 469-478.

[5.] Zemblyte, J. (2015). The Instrument of Evaluating E-Service Quality, Procedia-Social and Behavioral Sciences, 213, 801-806.

[6.] www.poczta-polska.pl (odczyt 21.11.2019).

[7.] -Baran, J. \& Jankoska, A. (2017). Preferencje polskich konsumentów dotyczace zakupów internetowych odzież, Problemy Transportu i Logistyki, 3(39), 87-94. 
[8.] Jaciow, M. \& Wolny R. (2011). Polski e-konsument. Typologia, zachowania, One Press, Gliwice 2011.

[9.] Zehir, C. (2016). E-service quality and e-recovery service quality: effects on value perceptions and loyalty intentions, Procedia- Social and Behavoral Sciences, 229, $427-$ 443.

[10.] Kowalik, K. \& Klimecka-Tatar, D. (2019). E-servqual jako metoda oceny jakości cyfrowej usługi pocztowej, [w:] Ulewicz, R. \& Ingaldi, M. (red.) Quality Production Improvement. Nowe wyzwania,Oficyna Wydawnicza SMJiP, Częstochowa, 109-118.

\title{
DIFFERENT APPROACHES TO THE GAP MODEL THE DETERMINANTS OF DIGITAL POSTAL SERVICE QUALITY MANAGEMENT- THE CHOSEN PROBLEM
}

\begin{abstract}
The objective of the article is to present the meaning of the chosen determinants in shaping digital postal service quality. The first part contains the theoretical framework of service quality management, the characteristics of postal market and digital postal services. Afterwards, the results of empirical research have been presented. Anonymous survey, regarding the evaluation of digital postal service quality determinants, has been conducted among fifty customers using digital postal services. The results contributed to the formulations of conclusions on the validity of chosen determinants of the digital postal service quality.
\end{abstract}

Key words: digitalization, quality determinants, quality, quality management

Data przestania publikacji do Redakcji: 28.09.2019

Data akceptacji publikacji przez Redakcję: 10.12.2019

DOI: 10.30657/qpi.2019.11.07 